\title{
KWL-Plus Effectiveness on Improving Reading Comprehension of Tenth Graders of Jordanian Male Students
}

\author{
Mohammad Hussein Hamdan \\ College of Languages and Translation, Al-Imam Muhammad Ibn Saud Islamic University, Kingdom of Saudi Arabia
}

\begin{abstract}
The main purpose of the study is to examine the effectiveness of the KWL-Plus strategy on the performance of the Jordanian Tenth Grade male students in reading comprehension. To achieve this aim, the sample of the study was selected from a private school and a public school. They participants were divided into an experiment group and a control group. All the public school students represented the experimental group. Whereas, the private school students represented the control group. The experimental group was taught reading with the KWL-Plus strategy, while the control group was taught with the conventional reading strategies. To collect the data, pre and post reading comprehension tests were administered. The pre-test was conducted prior to the application of the strategy, and the post-test was given to the students in the two groups after the application of the strategy. Data were analyzed by using mean scores, standard deviation, $t$-test and covariance. The findings indicated that the experimental group of the public school scored higher on the reading comprehension post-tests than their peers did in the control group. The researcher concluded that the strategy was effective in improving the reading comprehension performance and recommended that the strategy should be integrated into the English curriculum of the Jordanian schools.
\end{abstract}

Index Terms - KWL-plus, reading strategies, reading comprehension

\section{BACKGROUND}

Researchers, Johnson, Symons, McGoldrick, and Kurita (1989) indicated reading comprehension strategies were neglected as a formal component of schools curriculum until the 1970s. Since then, the significance of reading comprehension strategies has been realized by many research studies. Short\& Ryan (1984), Rosenshine, Meister, and Chapman (1996) have indicated that students employing reading strategies in their reading classrooms are more capable to understand reading texts than students who do not apply reading strategies.

English language teaching in Jordan has changed significantly in the last 25 years, in terms of content, pedagogy, assessment, and achieved learning outcomes. Obaidat (1997) pointed out that English education in Jordan is instrumental. It is meant to enhance better cooperation and communication between Jordan the international community.

English education is in Jordan at public and private schools starts as early as the first grade when children are at the age of six, and it continues up to grade twelve when students reach the age of 18. Al-Jamal (2007) indicated that Jordan Ministry of Education has worked tediously on improving English education. It has started to call for integrating new methodologies and instructional techniques for the four English language skills, particularly, employing new reading strategies that give learners many opportunities for discussion, participation and writing about what they have learned from reading texts.

The current study introduces the KWL-Plus as a new meta-cognitive reading strategy to the Jordanian schools educational context. The researcher has found that through an open survey distributed to 100 English teachers who teach seven through ten grades in 50 private and 50 public schools that none of them is familiar with the KWL-Plus strategy. The survey has one open question requesting the teachers to list all the reading strategies they apply in their reading classrooms of the English language. Accordingly, the researcher realized that the Jordanian teachers of English needed to be introduced to new reading strategies that contribute to better English education in Jordan.

\section{INTRODUCTION}

\section{A. KWL-plus as Related to Reading Comprehension}

Several studies about teaching reading strategies have been conducted. Reading comprehension involves more than decoding written words, rather than it is a complex process of interpreting text meaning (Pearson and Duke, 2002). Researchers indicated that new reading strategies were necessary to prepare proficient readers and to provide them with opportunities of success in their reading lessons and other school subject areas. (Davis \& Winek, 1989) \& (Weisberg, 1988). 
Research indicates that using effective reading strategies work effectively towards enhancing reading comprehension by using meta-cognitive strategies (Trabasso, Boucharad, 2000). It is evident that students who use proper reading strategies become efficient readers (Pressley, Johnson, Symons, McGoldrick, and Kurita, 1989; Short, Ryan, 1984).

Tracey and Morrow (2002) point out good readers who use meta- cognitive reading strategies before, during, and after reading can monitor better reading skills such as understanding and making predictions as they read. They are also more capable to summarize after they read.

The KWL Plus strategy is one of the meta-cognitive strategies intended to provide students with better opportunities of comprehending reading texts. Pressley (2000) suggests that proficient readers use appropriate comprehension techniques. Tracey and Morrow (2002) along with Pearson and Duke (2002) maintain that comprehension is a skill that enhances other language arts components such as decoding meaning, vocabulary development and spelling acquisition.

KWL-Plus as presented by Ogle (1987) is one of the reading meta-cognitive strategies that prompt the reader to think critically while interacting with the reading text.

The strategy has set of procedures to be used in English classrooms of reading. Teachers of English can use it with a group of students. First, the teacher introduces the reading lesson through a set of questions that help the students activate their prior knowledge of the present text. Second, the teacher prompts the students to write a few sentences about what they expect to learn about the text. Next, the teacher asks the students to read the text. Finally, the teacher requests the students to map the related ideas they learned from the text on specially designated worksheets. The main ideas can be turned into a writing task by summarizing the information they have already mapped in the previous activity. Thus, the teacher can assess the students' comprehension output from what they have already written about the target text.

The KWL-Plus strategy initially was introduced with three letters that represent the strategy main components. The first letter, "K" stands for "What I KNOW", "W" stands for "What I NEED to Learn", and finally the letter "L" stands for what I LEARNED. The "K", the first component, is an excellent way to activate the prior knowledge of readers. It raises student's awareness of the target text. Thus, students begin to make connections between their prior knowledge and newly acquired information. (Ogle, 1987). Ogle, finally, added the fourth component with the word "Plus" to include the writing skill by mapping the information and summarizing the text. Writing a review of the mapped information represented in the "Plus" component involves the students in writing a summary in their own language of the text. The "PLUS" engages readers in constructing meaning from text and helps them to become independent readers.

\section{B. Research Problem}

The researcher has noticed that Jordanian English teachers use almost one set of reading strategies among which no meta-cognitive strategies as KWL-Plus was used. In an open survey (Appendix 1) of a pilot study conducted on 70 teachers of English in 10 Jordanian public schools and 10 private schools teaching grades seven through ten, the researcher asked the English teachers to list down all the reading strategies they use with their students. He found that none of them listed KWL-Plus.

This study examines the effect of the meta-cognitive strategy, the KWL-PLUS, on improving reading comprehension of Tenth Graders of Jordanian students. It aims at improving tenth graders' abilities to construct meaning from text.

\section{Research Questions}

The study begins with the hypothesis that students' reading level at the same grade level, and the same school genre, would make the same general types of reading comprehension problems and that these problems would disappear or become negligible as KWL-Plus strategy is applied in reading classrooms.

More specifically, the study attempted to answer the following research questions:

1. Are there any statistically significant differences between the experimental and control groups of the tenth graders in the public and private schools on the reading comprehension pre-test before using the KWL-Plus strategy?

2. Are there any statistically significant differences between the experimental and control groups of the tenth graders in the public and private schools on the reading comprehension post-test after using the KWL-Plus strategy?

3. Does the KWL-Plus strategy have any effects on improving Jordanian students' reading comprehension performance in the experimental group?

\section{Significance of the Study}

The study is significant for the following reasons. First, at a theoretical level, the results will contribute to the cumulative body of research based on the theory of the relationship between reading development and other literacy skills such as writing. Second, this study suggests instructional implications and strategies for Jordanian teachers who teach English as a second language. Second, at a more general level, the results of the study will help to identify reading problems at each school types (public and private) and will reveal whether students at public schools possess the same reading abilities that their peers at private schools have.

Finally, the introduction of this new strategy is congruent with the Ministry of Education demands. The ministry has been working hard for the last 10 years on reforming education. It calls for the introduction of new methodologies and instructional techniques (Obaidat, 1997). 


\section{RELATED LITERATURE}

Roozkhoon 1 et. al (20013) designed a study on an experimental and a control group of Persian students to examine the effects of using KWL strategy on their comprehension of culturally unfamiliar English texts. The experimental group was treated with the KWL strategy for the reading classes, and the control group was introduced to the reading sessions in a traditional way. The researcher concluded that the KWL strategy did not have any significant effect on the reading comprehension performance of the two.

Smaikomusk (2012) conducted a study with the purposes to investigate the effect of the KWL-plus technique on grade 9 students' reading comprehension. Data analysis revealed there were no significant difference between the overall mean scores of students' pre- and post- reading comprehension tests. However, he students' opinions toward using this technique showed that they were satisfied with KWL-plus technique.

Fengjuan (2010) conducted a study on 80 university students majoring not in English to examine how the KWL strategy can be used by ELT for non-majors. Based on the findings of the study, the researcher indicated the KWL strategy had improved both the reading comprehension and the writing performance of the experimental group.

Sasson (2008) employed the KWL strategy to help struggling readers. The results brought evidence that the strategy helped the learners to become strategic readers.

Szabo (2007) used the KWL strategy to help struggling readers improve their understanding of the topics being studied. The results revealed that even students with autism, KWL strategies could make reading more accessible and fun in their classroom.

Casey (2009), with the presentation of reading activities through the KWL strategy, found out that the learners improved their ability in grasping meaning.

Glazer, (1999) aimed to use the KWL strategy to develop the skills of reading comprehension and reports writing of ninth-grade students. The researcher concluded that the ninth-grade students have developed not only the skills of understanding and comprehension of the texts in the target books, but also have developed their report writing skills.

Jared, (1993) used the (KWL-Plus) strategy it examine if it can significantly improve the sixth grade students understanding of the transportation system. The researcher concluded that the improved KWL-Plus strategy improved the students' reading comprehension of the transportation system, and it contributed to the introduction of the writing skill, particularly in the fourth column.

Mandeville (1994) provided a new model of (KWL) strategy by adding a fourth column to make this strategy (KW.LA). "A" in the fourth column means (Affective) and asking "Affective Questions" that probe fifth grade students' interest in reading and improve their reading compression skills. The researcher concluded students' understanding and knowledge of the reading text have significantly grown.

\section{METHOD}

\section{A. Participants}

The population was all the tenth graders of Jordanian public and private schools for boys. The sample was 50 tenth grade students (25 students from each school). Both the public school named "Al-Omarieh" and the private school named "Philadelphia -International" belong to the same educational zone in the city of Amman-Jordan. Both the public school and the private school draw their students from the local urban community of the city of Amman. The public school uses both an English and Arabic curriculum, while the private international school uses mainly the English curriculum for all school subjects. All the subjects were native speakers of Arabic.

The classes were chosen on availability rather than random selection since the two schools included only one classroom in grade ten.

The age of participants was taken into account to make sure that age, as a confounding factor, is controlled and would not affect the reading efficiency level of the two groups. The participant's gender is also controlled as a confounding factor since all of the subjects of the study belonged to two schools for boys. By accessing the records of the study participants at the registration office of each school, the researcher found that age average was about 16 years.

The researcher also wanted to make sure that the two groups in each school were almost equivalent in their reading proficiency level prior to the application of the reading strategy. The researcher accessed the students' grade records, and it turned out that all subjects in the two groups received "Grade One" implying that the study participants mastered all the basic reading skills.

\section{B. Material}

Two non-seen reading comprehension texts were chosen for the study tests; one was for the pre-test (Appendix 2), and the other one was for the post- test (Appendix 3). Each text included a multiple choice-questions test and a retention test in which the study subjects were supposed to summarize the text information in writing. The two reading comprehension texts were selected from the teacher's manual of New Headway Pus (intermediate series, 2006). Liz and John Soars wrote it. The ministry of education of Jordan for grade ten students' English curriculum adopted this textbook. 
The pre-test was conducted prior to the application of the strategy, and the post -test was administered after the application of the KWL method. The tests included multiple-choice questions (20 items) and one retention test (one open-end question) for summarization. For the retention test, the students were supposed to present 20 units of information in their summarized information in a form of writing, based on the information they read in the text. They were encouraged to write as much information units as they could recall from the retention text while they were trying to answer the open-end question.

Four arbitrators, who were full time teachers of English with an over 5-year teaching experience tested the reliability of the two tests. They were asked to score the validity of each item for the two tests (the multiple-choice questions and the retention tests). The four arbitrators' scores were collected, and their correlations were computed by using Stat View ${ }^{\circledR}$ software. The raters' scores showed a high reliability scale. The multiple choice test correlations were $(\mathrm{R}=.98)$, and the retention test correlation was $(\mathrm{R}=.96 .25)$. The correlation value of the two scales $(\mathrm{R}=.98 . \& \mathrm{R}=.96 .25)$ indicated that the two scoring scales were highly reliable.

\section{Procedure}

The researcher used quasi-experimental approach through which there were two groups; an experimental group $(\mathrm{N}=25)$ and a control group $(\mathrm{N}=25)$. The experimental group was the public school subjects who were taught reading with the KWL-plus strategy, while the control group was the private school subjects who were taught with traditional reading methods.

\section{Data Collection}

The pre-test was conducted on the Experimental and Control groups in each school prior to the application of the KWL-Plus strategy and during the first two weeks of the scholastic semester of the year 2013. The pre- test was given on two sessions; the multiple choice questions test was first administered at the second morning session of the school day, and the retention pre-test was administered later on the same school day after the 10:30 am school recess. The reading retention test was conducted at a different session because the students were not supposed to look at the reading text while they were writing their summaries.

After administrating the pre-tests, the schools teachers received training on using the KWL-Plus reading strategy as it is prescribed in the training manual (Appendix 4). Training was given for one week and right after the pre-tests. Teachers started using the KWL-Plus strategy with the experiment group in the public school at the beginning of the third week until the end of the twelfth week of the first semester. However, the control group of the private school continued to receive reading instruction with traditional reading strategies.

The post-tests were conducted in week 13, toward the end of the scholastic first semester, and after the application of the KWL-Plus strategy. The results of the pre-test and the post-test were reported and analyzed using the appropriate statistical methods.

\section{RESUlts}

To analyze the data, the following statistical techniques were used:

- The use of covariance analysis to measure the performance of students in the two groups; the experimental and the control on the pre- tests (The reading comprehension retention test and multiple-choice questions tests).

- The mean scores and standard deviations were employed to measure the tenth grade students' performance on reading comprehension before and after applying the KWL-Plus technique.

T-test was used to measure the differences between the mean scores of the experimental group of the public school and control group of the private school on the post- tests of reading comprehension.

The first question attempted to find out if there are there any statistically significant differences between the experimental and control groups of the tenth graders in the public and private schools on the reading comprehension pre-test before using the KWL-Plus strategy.

Table (1) shows that the mean score of the pre-test of the experimental group was (5.55) with a standard deviation (2.88). The mean score of the control group is (5.69) with a standard deviation (3.18). The findings indicates that he mean scores of the private school subjects are a little higher than their peers in the public school. Table (2) below give a statistical account for the mean scores differences of the two groups.

TABLE 1.

READING COMPREHENSION MEAN SCORES OF PRE-TESTS FOR THE EXPERIMENT AND CONTROL GROUPS

\begin{tabular}{|l|l|l|}
\hline Pre -Test & Group \\
\hline Standard Deviation & Mean Score & \\
\hline 3.18 & 5.69 & Control -Private \\
\hline 5.88 & 5.55 & Experimental -Public \\
\hline
\end{tabular}

In table (2), the statistical (P-value) is (6.19) at the level of probability (0.02) which is significant at the level (0.05). The finding indicates that there are no statistically significant differences of students' performance on the pre-tests (The multiple choice and retention tests) between the experimental and control groups. 
TABLE 2.

\begin{tabular}{|l|l|l|l|l|l|}
\hline \multicolumn{2}{c}{ COVARIANCE ANALYSIS RESULTS FOR THE PRE-TESTS FOR THE EXPERIMENT AND CONTROL GROUPS } \\
\hline P- Value & ( F $)$ & Chi-Square Mean & Degrees of freedom & Chi-Square & Source of Variance \\
\hline 0.02 & 9.19 & 68.76 & 1 & 68.76 & Pre- Test \\
\hline 0.00 & 51.07 & 567.76 & 1 & 567.76 & Group \\
\hline & & 11.12 & 49 & 544.70 & Error \\
\hline & & & 51 & 1181.22 & Total \\
\hline
\end{tabular}

The second question attempted to find out if there are any statistically significant differences between the experimental and control groups of the tenth graders in the public and private schools on the reading comprehension post-tests after using the KWL-Plus strategy.

Table (3) shows that the mean score for the post-tests of the private school control group was (6.03) with a Standard Deviation (2.88). Whereas, the mean score of the public school experimental group on the post-test is (8.55) with a Standard Deviation (2.14). Descriptive statistics in this table indicated the experimental group obtained higher grades on the post-tests than their peers in the control group did. Table (4) below will provide a statistical account for these differences.

TABLE 3.

MEAN SCORES AND STANDARD DEVIATIONS OF POST-TESTS FOR THE EXPERIMENT AND CONTROL GROUPS

\begin{tabular}{|l|l|l|}
\hline Post-test & Group \\
\hline Standard Deviation & Mean Score & \\
\hline 2.63 & 6.03 & Control- Private \\
\hline 2.14 & 8.55 & Experimental- Public \\
\hline
\end{tabular}

The statistical (T- value) in Table (4) below is (-9.75) at the level of probability (0.02), which is significant at the level (0.05), this indicates that there are statistically significant differences in students' performances on the reading comprehension post- tests (The multiple choice and retention tests).

TABLE 4.

\begin{tabular}{|} 
T-TEST RESULTS FOR THE EXPERIMENT AND CONTROL GROUPS ON THE READING COMPREHENSION POST-TESTS \\
\begin{tabular}{|l|l|l|l|l|}
\hline F-Value & T & Standard Deviation & Average & Group \\
\hline 0.00 & -9.75 & 2.66 & 6.03 & Control -Private \\
\hline & & 2.88 & 8.55 & Experimental- Public \\
\hline
\end{tabular}
\end{tabular}

Question 3 attempted to investigate whether the KWL-Plus strategy has any effects on improving Jordanian students' reading comprehension in the experimental group. The findings represented in tables (3) and (4) above gave a-by-default answer to this question. The results indicated that there were statistically differences between the experimental group of the public school and control group of the private school on the post-tests. The result confirmed the effectiveness of the KWL-Plus strategy on the experimental group of the public school students.

\section{DISCUSSION}

As for question \# 1, "Are there any statistically significant differences between the experimental and control groups of the tenth graders in the public and private schools on the reading comprehension pre-test before using the KWL-Plus strategy?", Data Analysis revealed that there were no statically significant differences between the experimental group of the public school students and the control group of the private school students on their performance on the prereading comprehension tests. The result is expected in this study as there was no evident reading strategy employed by the English teachers in the two schools genres.

The findings of the second question support findings conducted by other researchers, as the KWL-Plus was effective and it improved the reading capabilities of the experimental group. (Rahmawati 2014; Erawati, 2012; Smaikomusk, 2012; Fengjuan, 2010; Sasson; 2008; Szabo, 2007; Casey, 2009; Al Shaye, 2000; Piper, 1992; cited in Al Khateeb 2010) reported that KWL is an effective reading strategy to improve reading comprehension of the students. Thus, these findings are in harmony with the findings of question \# 2, which indicated a higher performance of the experimental groups for the public school students than their peers of the control group in the private school.

With respect to question number 3, "Does the KWL-Plus approach have any effects on improving Jordanian students' reading comprehension in the experimental group?" The findings pertaining to question \# 2 consolidated the effectiveness of the strategy on the experimental group.

However, the researcher expected that the performance of the control group in the private school would be better or the same of the experimental group since the private school adopts an international curriculum where English is used as a medium of instruction for all school subjects. In other words, the students of the private school were anticipated to have better English language skills including reading.

In conclusion, KWL-Plus technique was useful and effective for students in improving their reading experience. The students were more capable of summarizing the reading passages, mapping the main ideas and better comprehending the text. The method put students of the experimental group on a task that increased their ability to read and 
comprehend. This conclusion was consistent with Norasing's study (1997) who stated that almost all students were interested in KWL-Plus method as it increased the students' readability power towards reading comprehension.

Based on the findings of the present study, the KWL- Plus method is effective in boosting students reading comprehension abilities. Therefore, the teachers of English language in Jordan ought to try to include this strategy in teaching reading in Jordanian schools. Consequently, it is recommended that future research should be conducted on high school and undergraduate university students by using the KWL- Plus technique. Higher -level Jordanian students are anticipated to perform better with this strategy because they are more likely to have sufficient prior knowledge to do reading tasks that are more challenging in their English textbooks.

However, the present study has its limitations. A major limitation would go to the time devoted to this experimental study. Pressed schedules of the school English syllabus limited the instructors to give enough time for performing KWL- Plus steps and stages.

Another limitation was the unfamiliarity of teacher with KWL-plus process. The teachers in the two schools were noted to go back and forth looking at the strategy manual. This conspicuous classroom behavior was time consuming and constituted an obstacle to applying the strategy steps on a timely manner. The time factor for applying the strategy was crucial as there were deadlines for both the teachers and the students to accomplish each reading task.

\title{
APPENDIX 1. OPEN SURVEY OF ENGLISH TEACHERS
}

\author{
Teacher's Name- \\ School name \\ (Private or public) Please circle your school type. \\ Teacher's signature: \\ Note: Your signature indicates your approval to participate in the study
}

List down all the reading comprehension strategies you use in your reading classes:

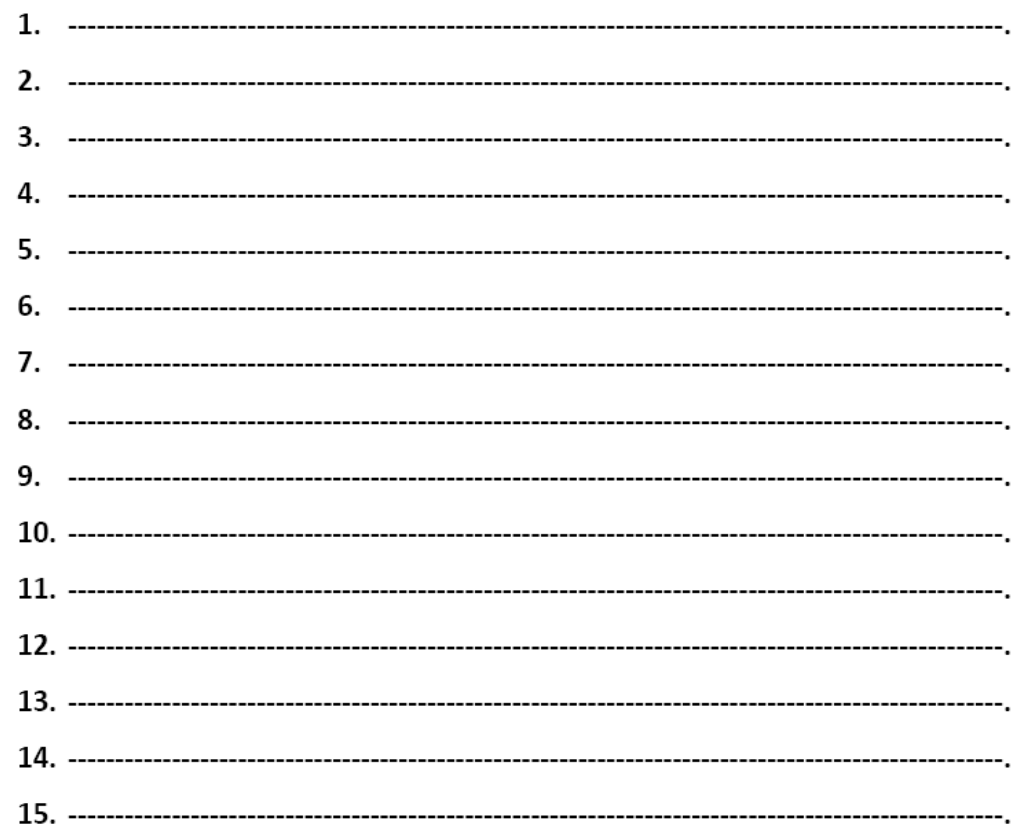




\section{ApPendix 2. Reading Multiple Choice \& Retention Pre-Test}

\section{My ideal holiday}

1. My ideal holiday has a little bit of everything. I like lazing on a beach with a pile of books, but then I get bored and I need to do something. I like exploring new places, especially on foot, and nosing around in shops, museums, and restaurants. I'm very into trying local foods.

2. However, I must confess that my favourite holiday resort' is home. I travel so much in my job that just waking up in my own bed is heaven. I potter around the house in my pyjamas, read the paper, do some gardening, shop for some food, then make a delicious meal in the evening and watch TV

\section{My business holidays}

3. I have three trips coming up. I'm looking forward to going to Canada soon, where I'm staying for four nights at the Ice Hotel. This is a giant igloo situated in Montmorency Fall Park, just 20 minutes from downtown Quebec. It is made from 4,500 tons of snow and 250 tons of ice, and it takes 5 weeks to build. It will stay open for three months. When the spring arrives, it will melt. Then it will be built again for next year - maybe in a different place! Each room is supplied with a sleeping bag made from deer skins. The hotel has an ice cafe, ice sculptures, and all the furniture is made of ice.

5. In complete contrast to the Ice Hotel, I'm going to Dubai the following month, to stay a few days at the spectacular Burj al-Arab, which means the Arabian Tower. It's shaped like a giant sail, and it rises dramatically out of the beautiful blue water. Each room has sea views. I really want to try the restaurant in the tube at the top next to the helipad. Other must-dos include shopping in the markets, called souks. (You can buy designer clothes, perfumes, and spices, but what I want is some gold jewellery for my mother.) I'm also going to visit the camel races. 6. The next trip, different again, is to Baobab Rivers, in Selous, Tanzania, for a seven-day safari and I'm looking forward to a visit to my favourite resort spas.
Choose The correct answer from a, b, or c (20 Marks).

1. We can conclude from the passage that the narrator's holidays are:

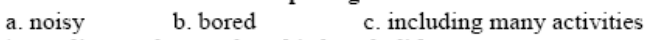

2. According to the speaker, his best holidays are:

$\begin{array}{lll}\text { a. in museums b. at home c. at restaurants } & \text { c }\end{array}$

3. The passage indicates the speaker---o----.
$\begin{array}{lll}\text { a.is single } & \text { b. has family } & \text { c. is married }\end{array}$

4. One of the activities the narrator is NOT doing at home is:

a. reading the paper b. gardening c. listening to music

5. When the speaker spends his holiday at home, he-

$\begin{array}{lll}\text { a. orders foods } & \text { b. cooks food c. eats food with friends }\end{array}$

6. The closest meaning of the underlined word ""NOISING" in the first paragraph is -

$-a^{-10}$

$\begin{array}{lll}\text { a. moving } & \text { b. annoyed } & \text { c. bored }\end{array}$

7. His next trip is going to be to --

$\begin{array}{lll}\text { a. Tanzania } & \text { b. Dubai } & \text { c. Canada }\end{array}$

8. The underlined pronoun "IT" in the third paragraph refers to-----.

$\begin{array}{lll}\text { a. Quebec b. Fall Park c. the Ice Hotel } & \end{array}$

10. What do we conclude about the Ice Hotel? It is

$\begin{array}{lll}\text { a. easy to build } & \text { b. permanent } & \text { c. built again\& again }\end{array}$

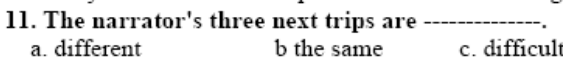

12. In the Ice Hotel, the sleeping material is made of

a. ice b. ice and leather c. deer skins

13. The underlined word "SPECTACULAR" in paragraph 5 means:

$\begin{array}{lll}\text { a. huge } & \text { b. giant } & \text { c. remarkable }\end{array}$

14. The Ice Hotel is open -

$\begin{array}{lll}\text { a. during winter } & \text { b. in summer } & \text { c. for the whole year }\end{array}$

15. Why do you think the narrator's trip to Dubai is in contrast to the Ice Hotel? Because of--

a. weather change b. long distance c. money expenses

16. The expression "a giant sail" in paragraph 5 refers to --.--..

$\begin{array}{lll}\text { a. Burj al-Arab b. Dubai } & \text { c. a ship in Dubai }\end{array}$

17. We can conclude from the passage that Burj al-Arab is mainly a -.-.--_-

$\begin{array}{lll}\text { a. hotel } & \text { b. restaurant } & \text { c. mall }\end{array}$

18. "Souks" are ---o-s.

a. shopping places b. food markets c. clothes factories

19. In Tanzania, the speaker is interested in a visit to

$\begin{array}{lll}\text { a. health resorts } \quad \text { c. Jewelry shops c. dinning places } & \end{array}$

$\begin{array}{ll}20 \text {. His trip to Tanzania is going to be - b. long } & \text { c. difficult } \\ \text { a. short } & \text { b. }\end{array}$ 


\section{Appendix 3. Reading Comprehension Multiple Choice Post Test}

\section{A BRIEF HISTORY OF PIZZA}

1. So you thought the burger was the world's most popular fast food? In fact, there is another truly universal fast food, the ultimate fast food. It's easy to make, easy to serve, much more varied than the burger, can be eaten with the hands, and it's delivered to your front door or served in fancy restaurants. It's been one of America's favourite foods for over 50 years. It is, of course, the pizza.

2. It's kind of silly to talk about the moment when pizza was 'invented'. It gradually evolved over the years, but one thing's for certain - it's been around for a very long time. The idea of using pieces of flat, round bread as plates came from the Greeks. They called them 'plakuntos' and ate them with various simple toppings such as oil, garlic, onions, and herbs.

3. The Romans enjoyed eating something similar and called it 'picea'. By about 1000 A.D. in the city of Naples, 'picea' had become 'pizza' and people were experimenting with more toppings: cheese, meat, anchovies, and finally the tomato, brought to Italy from Mexico and Peru in the sixteenth century. Naples became the pizza capital of the world.

4. In 1889, King Umberto I and Queen Margherita heard about pizza and asked to try it. They invited pizza maker, Raffaele Esposito, to make it for them. He decided to make the pizza like the Italian flag, so he used red tomatoes, white mozzarella cheese, and green basil leaves. The Queen loved it and the new pizza was named 'Pizza Margherita' in her honour.

5. Pizza migrated to America with the Italians at the end of the nineteenth century. The first pizzeria in the United States was opened in 1905 at 53lf2 Spring Street, New York City, by Gennaro Lombardi. But the popularity of pizza really exploded when American soldiers returned from Italy after World War 11 and raved about 'that great Italian dish'. Americans are now the greatest producers and consumers of pizza in the world.
Choose The correct answer from a, b, or c (20 Marks).

1. According to the passage, Pizza is a food of -------- history.
a. long
b. short
c. unknown

2. How is Pizza similar to Burger? Both of them are ---- foods.
a. fast
b. home-made
c. not eaten at home

3. According to the passage, pizza was originated in -------.
a. America
b. Italy
c. Greece

4. What is the Greek expression that is similar to the English word "plates"?
a. round bread
b. flat topping
c. plakuntos

5. The old Romans ate something
a. exactly the same as
b. similar to Pizza. developed in
a. America\& Greece
b. Italy
c. Mexico\& Peru

7. What Pizza component came from Mexico and Peru?
a. Tomato
b. Mazola cheese c. Anchovies

8. Raffaele is a name of a
a. king
b. queen
c. Pizza maker

9. The underlined pronoun "HER" in paragraph 4 refers to--
a. Umberto 1
b. Esposito
c. Margherita

10. The oldest food similar to Pizza was eaten in
a. Rome
b. Mexico
c. America
11. The Greek Pizza was cooked with toppings.

$\begin{array}{lll}\text { a. vegetables } & \text { b. meat } \quad \text { c. meat and vegetables }\end{array}$

12. The underlined pronoun "THEY" in paragraph 2 refers to--
a. the Greek people
b. anchovies
c. plates

13. Which century in the world's history experienced major developments of pizza? The --_ Century.
a. sixteenth
b. eighteenth
c. twentieth

14. The history of Pizza in America can be described as -- --
a. long
b. short
c. unknown

15. Basil leaved were first added to Pizza toppings in
a. America
b. Italy
c. Greece

16. The closest meaning of the underlined word "MIGRATED" in paragraph 5 is
a. eaten
b. cooked
c. travelled

17. Who made Pizza more popular in the United States?

a. Gennaro

b. The American soldiers of WWII

c. The Italians

18. Pizza came to America directly from
a. Rome
b. Greece
c. Italy

19. Which country do you think has contributed to spread Pizza to the rest of the world?
a. America
b. Greece
c. Italy

20. Which people of the world are the most producers and consumers of Pizza? The ------ people.
a. American
b. Italian
c. Roman 


\section{(KWL-PLUS Training Manual)}

KWL-PLUS Instructors' guide for Strategy implementation

The KWL-Plus helps students:

-Recall what is known (K); - Determine what students want to learn (W);

- Identify what is learned (L); and -Map text and summarize information (Plus).

\section{Procedures:}

1. Distribute copies of Activity Sheet to students, or create a class KWL organizer using chart paper.

2. Choose a topic and guide the students in a brainstorming activity to generate ideas regarding what they already know about this topic.

(K)

3. Guide students through the process of categorizing information in the $\mathbf{K}$ column. This "chunking" allows them to anticipate areas of information they may find in their research. Model the categorization process by thinking aloud while identifying categories and combining and classifying information. Students can complete the "Categories of Information We Expect to Use" section on the activity sheet or on chart paper if the process is being modeled with the entire class.

4. They can read the text independently or in small groups. Text should be in manageable segments until the student becomes familiar with the technique. Reading text in segments allows students to become aware of what they are learning as well as what they have not comprehended.

5. As they research, the student should note new information in the $\mathbf{L}$ column, which identifies what he/she has learned. This helps students select important information from each paragraph and it provides a basis for future reference and review.

6. Model how students should categorize information listed in the $\mathbf{L}$ column. Have students ask themselves what each statement describes. In doing so they often discover more categories that can be used for future reading.

The next step could be for students to create a map/web with the information. Through listing and categorizing, the most difficult tasks of constructing a map are already completed.

7. Instruct students to use the article title as the center (big idea) of their map. Categories developed with the KWL-Plus organizer become the map's major concepts, with explanatory details subsumed under each. Lines show the relationship of the main topic to the categories. All information categorized on the organizer acts as supporting data on the map.

8. Guide students in writing a summary of their data. The most difficult part of summarizing has already been completed.

9. Instruct students to use a map as an outline for their summary. The map's center becomes the title of the summary.

10. Students number the categories on the map in the sequence they prefer. Each category forms the topic for a new paragraph

11. Finally, supporting details in each category are used to expand the paragraph or explain the key ideas.

\section{ACTIVITY SHEET}

KWL-Plus Graphic Organizer

Topic:

\begin{tabular}{|l|l|l|}
\hline K (What I Know) & W (What I Want to Know) & L (What I Learned) \\
& & \\
\hline
\end{tabular}




\section{REFERENCES}

[1] Al Khateeb. (2010). The Impact of Using KWL Strategy on Grade Ten Female Students' Reading Comprehension of Religious Concepts in Ma'an City. European Journal of Social Sciences. 12 (3), www.eurojournals.com/ejss_12_3_14.pdf. (accessed 15/3/2014).

[2] Al Shaye. (2000). The effectiveness of metacognitive strategies on reading comprehension and comprehension strategies of eleventh grade in Kuwaiti high schools. PHD thesis, Ohio University, USA.

[3] Al-Jamal. (2007). English Teaching and Learning Experiences in Jordan: Attitudes and Views/Umm Al-Qura University. Journal of Educational \& Social Sciences \& Humanities, 19 (1), 28-55.

[4] Carr \& Ogle. (1987). K-W-L plus, A Strategy for comprehension and summarization. Journal of Reading 30:626-631.

[5] Casey. (2009). Using KWL strategies in reading for students with autism. http://www.brighthub.com/education/special/topics/autism.aspx (accessed 30/2/2014).

[6] Davis \& Winek. (1989). "Story map instruction: A road map for reading comprehension." The Reading Teacher, 43, (3), 232-240.

[7] Erawati, Ni. (2012). A Comparative Effect of Metacognitive Self-Monitoring Strategies on Students' Reading Competency Based on Text Types. E-Journal Program Pascasarjana Universitas Pendidikan Ganesha Program Studi Pendidikan Bahasa, 1 (1), 1-19.

[8] Fengjuan. (2010). The Integration of the Know-Want-Learn (KWL) Strategy into English Language Teaching for Non-English Majors. Chinese Journal of Applied Linguistics (Bimonthly), 33 (4), 77-86.

[9] Glazer. (1999). Using KWL Folders: A Three-section folder to encourage an independent Working environment for children, Teaching Pre-k- 8, 29 (4), 106-107.

[10] Jared, E. (1993). The effects of the K-W -L plus Comprehension Strategy on the Achievement of Preserves Teachers, unpublished Doctoral Dissertation, University of Missouri- Columbia.

[11] Johnson, Symons, McGoldrick, and Kurita. (1989). Strategies that improve children's memory and comprehension of text. The Elementary School Journal, 90, 3-32.

[12] Norasing. (1997). A comparison of matthayom suksa III students' reading performance, and reading attitudes through KWL-Plus reading teaching instruction based on Teacher's manual. Unpublished master's thesis, University of Srinakarinwirot, Bangkok.

[13] Obaidat. (1997). Evaluation of EFL In-Service Training Course in Jordan (Views and Practices). PhD Thesis. University of Bristol.

[14] Ogle. (1987). K-W-L-PLUS: A teaching model that develops active reading of expository text. Reading Teacher, 39, 564-570.

[15] Pearson and Duke. (2002). ).“Comprehension instruction in the primary grades.” In Comprehension Instruction. New York: The Guilford Press.

[16] Pressley. (2000). What should comprehension instruction be the instruction of?" Handbook of Reading Research, Vol. III. Mahwah, NJ: Erlbaum.

[17] Rahmawati, L. Nyoman, P. \& Made, R. (2014). The Effect of CIRC and Achievement Motivation on Students' Reading Comprehension. E-Journal Program Pascasarjana Universitas Pendidikan Ganesha Program Studi Pendidikan Bahasa. 3, 1-12. http://pasca.undiksha.ac.id/e-journal/index.php/jurnal_bahasa/article/view/1075/823(accessed 10/5/2014).

[18] Roozkhoon1 et. Al. (20013). Evaluating KWL Charts Strategy in relation to Iranian EFL Learners' Comprehension of Culturally Unfamiliar Texts. English Linguistics Research 2, (1), 72-85.

[19] Rosenshine, Meister, and Chapman. (1996). "Teaching students to generate questions: A review of the intervention studies." Review of Educational Research, 66 (2), 181-222.

[20] Pressley, Johnson, Symons, McGoldrick, and Kurita. (1989). Strategies that improve children's memory and comprehension of text. The Elementary School Journal, 90(1), 3-32.

[21] Sasson. (2008). Use K-W-L technique in reading lessons: Strategic thought process for engaging students before they read. http://newteachersupport.suite101.com/article.cfm accessed 4/4/2013).

[22] Short\& Ryan. (1984). Metacognitive differences between skilled and less skilled readers: Remediating deficits through story grammar and attribution training. Journal of Educational Psychology, 76, 225-235.

[23] Smaikomusk. (2012). The Effect of KWL-Plus on Reading Comprehension of Mattayom Suksa III Students at Watratcha O-Rot Achool. Master of Arts in Teaching a Foreign Language. Strinakharinwirot University.

[24] Soars, Liz\& Johns. (2006). New Headway Plus. Oxford, London.

[25] Szabo. (2007). The K-W-L strategy: Helping struggling readers build evidence of their learning. Thinking Classroom Journal, 8(2), 32-40. Retrieved on April 25, 2014 from http://ct-net.net/tc_ann_8-2_Sza (accessed 11/11/2013).

[26] Trabasso, Boucharad. (2000). "Text comprehension instruction." Report of the National Reading Panel: Report of the Subgroups. National Institute for Literacy.

[27] Tracey and Morrow. (2002). "Text comprehension instruction.” Report of the National Reading Panel: Report of the Subgroups. National Institute for Literacy.

[28] Weisberg. (1988). A change in focus of reading comprehension research: A review of reading/learning disabilities research based on an interactive model of reading. Learning. Disability Quarterly, 11, 149-159. 


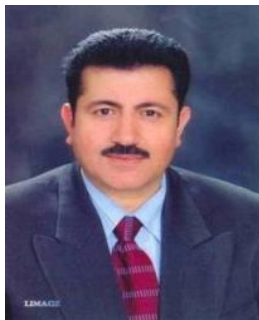

Mohammad Hussein Hamdan was born in Meqbeleh, Jordan in1962. He received his PH.D degree in Reading and Language Arts form Oakland University, Michigan, America in 2001.

$\mathrm{He}$ is currently an assistant professor in t the College of Languages and translation, Imam Muhammad IBN Saud Islamic University, Saudi Arabia. His research interests include reading, TEFL, semantics and translation.

Dr. Hamdan is a member of the Association of Professors of English and Translation of Arab Universities, Jordanian Association for Professional Translators, Jordan Society for Scientific Research, IRA: International Reading Association, ISTE: International Society for Technology in Education, NRC: Committee of the National Reading Conference, and TESOL Arabia: 